УДК 37.011:807.104(05-98)

DOI: $\underline{10.35619 / \text { iiu.v2i11.216 }}$

\author{
Nataliia Mykhalchuk \\ $\mathrm{PhD}$ in Psychology, Professor, \\ Head at Practice of English Language Department, \\ Rivne State University for the Humanities, \\ Rivne, Ukraine \\ ORCID: 0000-0003-0492-9450 \\ e-mail:natasha1273@ukr.net
}

Ernest Ivashkevych $\mathrm{PhD}$ in Psychology,

lecturer at Practice of English Language Department, Rivne State University for the Humanities,

Rivne, Ukraine

ORCID: 0000-0001-7219-1086 e-mail: ivashkevych.ee@gmail.com

\title{
INNOVATIVE MEANS FOR TESTING KNOWLEDGE, SKILLS AND ABILITIES OF ADOLESCENTS AT THE LESSONS OF FOREIGN LANGUAGES
}

\begin{abstract}
In this article we found out the ways of creating innovating means for testing pupils' skills, abilities and knowledge which not only help the teacher to control teenagers' process of studying, but also are directed on the development of pupils' person. In this article we proposed the stages of pupils' activity with text material which are based not only on information of the text but also on own experience of pupils.

It was shown that the first stage (pretext) was implemented before reading the text. Exercises at this stage are aimed at predicting content and semantic information of the text, as well as the removal of possible difficulties in the phonetic, lexical and grammatical nature. The second stage (textual) is the reading of the entire text silently. The reading process can take place in the classroom or at home by the teacher's instructions. The third stage (post-text) involves performing tasks to control the understanding of the content of the text having been read, as well as exercises aimed at assimilating the linguistic means that provide the skills for operating by pupils these tools in their own statements at the level of the phrase or unpublished unity in connection with the content of the text. The fourth stage is the stage of performing speech exercises, the purpose of which is to develop pupils' abilities to make fluent oral monologues on the basis of semantic information of the text. Exercises with problematic tasks are carried out, which are based not only on information of the text but also on own experience of pupils.

Key words: innovating means, testing, pretext stage, textual stage, post-text stage, stage of performing speech exercises.

Problem statement. The actuality of the research is determined by the introduction of effective means of testing for the acquisition of English by schoolchildren, which in a great degree influences the effective dialogue communication of adolescents in the process of teaching foreign languages at Ukrainian secondary schools, which will make the process of studying more effective and bring it closer to world standards.
\end{abstract}


Therefore, we'll see the topic of this research in the description and substantiation of test methods for pupils who learn foreign language material, with the aim to make control according to skills and abilities of adolescents at the English lessons at secondary schools, which promote effective dialogical communication between schoolchildren with each other and a teacher.

Research aim is to find out the ways of creating innovating means for testing pupils' skills, abilities and knowledge which not only help the teacher to control teenagers' process of studying, but also are directed on the development of pupils' person. The main tasks are to propose the stages of pupils' activity with text material which are based not only on information of the text but also on own experience of pupils.

Presenting the main research material. According to a new program of Ukrainian education, the amount of pupils' words at the end of the second class should be at least four phrases. It can be brief announcements about certain events, description of some phenomena and objects. In the third form pupils at the end of a school year must still be able to convey the contents of texts having been read or listened, have to express their attitude to something or someone, using at the same time not less than six phrases (Oller, 1989). In the next class the program provides the formation at the end of the academic year the ability to convince the interlocutor in something. Accordingly, the volume of the statement also increases. A pupil already has to speak not less then eight sentences.

Pupils in the fifth form should, according to the program, be able (without pre-training) logically and consistently, according to different training situations to make an expanded message on the topic, to transmit in its words the contents of read or heard information in the form of a narrative, a description, and also make a prepared message, independently picking up the material and using additional information (Alderson, Clapham \& Wall, 1995). The volume of the statement reaches 12 phrases, in the seventh form the amount of them is 14 . In the next class pupils should be able to discuss topics within the spheres of communication indicated by the program; they have to be able to use the functions provided by the content of the program: to express their beliefs, opinions, consents or disagreements in response to receive information; give concise examples or explanations to a plan or an idea; tell the story, the plot of the book and express their attitude to them. Speech volume is at least 16 phrases. At the end of the ninth form this volume is increased to 18 phrases, and at the end of the twelfth grade it is 22 phrases. In accordance with the requirements of the program from year to year the level of complexity of tests aimed at verification of abilities and skills of monologue speech is complicated.

So, at first pupils can be offered to do tests, to use a complete verbal support. In the future it is replaced by an illustrative support, which will tell the sequence of descriptions. In addition to full verbal supports there are partial / incomplete verbal supports in the form of open table substitutions, structurally-speech schemes and logical-syntactic statements (Bachman, 1991).

So, we'd like to emphasize that all tasks must have a cultural orientation. For example:

1. Your friend who lives in the UK is about to visit you next year. Imagine this moment when you talk to him on the phone. Ask him about yourself. Describe the weather in Ukraine. Use the substitution table.

1. In... it's...

2. The sun ... every day.

3. The sky is...

4. Sometimes it... rains snows.

5. A wind blows.

2. Betty is interested how we celebrated the New Year. Write her a letter, but at first tell how Ukrainians celebrate this holiday. This will help you with this scheme: 
1. In Ukraine the 1-st of January, New Year's Day, is...

2. People do not go...

3. The holiday begins on the...

4. Relatives and friends come to...

5. After 12 o'clock some young people go out into...

In this situation you can also use a logical syntactic scheme that defines the logical sequence of expressions, but allows the content to vary, depending on the actual events and interests of pupils. According to the partial verbal supports you can also include a statement of words and keywords. The plan is sometimes presented in the form of nominative sentences, as well as in the form of questions (Oller, 1989).

3. You visit your friend who lives in the UK who fell ill a few days ago. Now, of course, it is much better. Speak with him, inquire about his/her health, tell him/her how your friends spend their free time in the village. Do not forget to tell about the weather. The key words and phrases will help you to answer:

1) spent the weekend in the country / in a small town / in a big city;

2) went there by train / by bus / by car / on foot;

3) the weather was... . It... . The ice seemed... .

4) rode a horse / in one horse open sleigh;

5) skied down steep slopes.

6) skated on the pond / on the lake / on the river.

You can also use mixed verbal-figurative supports. They may plan an apartment with room names, a school plan with a designation of offices, a schematic plan as a part of the letter. In the process of testing a dialogue speech, the teacher can use separate drawings, slides. Subsequently, the teacher can propose tests without the use of supports.

It is generally acknowledged that the constant use in the educational process of being studied materials that have educational and developing potential, forms that are interesting for pupils to study a foreign language, with which there are significant reasons of improving the effectiveness of studying the foreign languages. Therefore, it is no coincidence that one of the problems having been discussed according to the modern methods is the problem of providing pupils with knowledge in the field of regional studies and the application of this knowledge in the process of teaching foreign language communication. In the absence of the linguistic environment, which, without a doubt, is the main source and at the same time an incentive for learning, in particular, dialogical speech, may be printed in a foreign language text.

The selection of colored material should be conditioned by the spheres and forms of a real foreign language communication of pupils, the real reserve of linguistic resources, the possibilities of using the obtained regional knowledge information, knowledge learned by pupils at the lessons from the foundations of science, the diversity of cultures and the contemporary activities of the countries having been studied.

Texts of a regional nature may include information about the geographical location and natural features of the country having been studied, on the city's sights, progressive public figures, traditions and holidays, classics of literature, outstanding artists and composers; materials about folk art, about lifestyle and social structure, about the lives of schoolchildren and youth.

It is important to involve into the educational process materials that reflect the cultural and historical features of the country and our native land. A special place in the selection of tests is the information from the press. In the early stages of providing activities with new material, it is advisable to use short messages, headings of various articles, correspondence and signatures under illustrations. They are convenient to actualize the conciseness and relatively small number of 
unfamiliar words (Ніколаєва, 1996). They attract pupils with their urgency and allow the teacher to expand the subject of the texts from the textbook. The category of learning methods in the best way can bring pupils closer to the natural cultural environment, in such a way tests have to include, first of all, authentic texts. These texts should contain factual material that is interesting to pupils and satisfies their sphere of interests, focused mainly on such topics:

1. Youth culture of adolescents in the West.

2. Everyday life of pupils abroad.

3. Education in the UK, USA and other countries.

4. Outstanding people in the countries of study.

5. Royal Family.

6. Nature Conservation in the UK, USA and other countries.

7. Questions of religion and religion in the United Kingdom and the United States.

8. Sports (favorite sports teams and youth idols abroad).

9. Cities of the countries to be studied.

10. National heroes of the countries being studied.

11. Scientific achievements.

12. Humor of the peoples of the United Kingdom and the United States.

These are such texts that need to be taken away when developing the tasks for testing with the purpose of the formation of skills and abilities of monologue and dialogue speech of pupils.

The tests for the verification of dialogical speech, based on authentic texts of the English language, include:

1. Respondent (answers to questions) and reactive tasks, conditional conversation.

2. Objectives of reproductive nature (transfer of message, information).

3. Tasks of a discursive nature (commentary, discussion).

4. Compositional tasks (oral works based on the material, free story).

5. Initiative tasks (press conference, interviews).

Answers to questions are considered to be the most popular tasks in the teaching method of a foreign language.

Transmission as a conscious reproductive speech activity is the direct preparation for arbitrary expression of thoughts during dialogue communication. Depending on the method of organization, the transfer can take place both in the conditional and in a real-motivated situations.

Translation as a kind of test can be differentiated depending on the nature of the source of a text, the way it is presented, the methodological setting and organization of the activity in the class. At secondary school all types of texts can be used in terms of their content structure - description, narrative and informational. The content of the text can be reproduced completely or abbreviated, as the abstract or a selective one.

The next kind of test is statement on the basis of a problem situation. The essence of this test is the awareness and decision of the pupils of a certain extra-linguistic task, which is accompanied by the "extradition" of the predictive speech product. From the speech situation, the problem differs by "depersonalized" (in relation to the speaker) circumstances, by exteriorization of the speech stimulus, the variability of the successive operations. In addition to the theme-task and exposure, the structure of the problem situation also includes the question of updating its content and instructions for speech actions. The exposition is a verbal description of a certain coincidence of real (imaginary) circumstances that implicitly contain some contradiction or a problem.

The next kind of test is comment. The essence of this type of test is that the speaker after receiving certain information explains his/her attitude to the text and expresses in this regard his/her judgment comparatively, according to generalizing or appraisal nature. Objectives of commentary 
may be, for example, an invitation, a theatrical program, an advertisement, newspaper or magazine articles, international events, humorous drawings, etc.

The next kind of test is oral story. This is the main form of test of a composite nature. It is a monologue in the form of a presentation which can be both prepared and unprepared. There are the following types of stories:

1) ready-made plot in curtailed form;

2) according to the proposed situation;

3) on the proposed topic;

4) by proverb, winged expression;

5) by their own subject, the pupils selected in connection with the materials having been read.

The next kind of test is the activity on both with the informational and the linguistic basis of the text for the development of dialogue skills involved four phases, each of which includes a set of exercises and tasks aimed at the consistent seizure of information from the text and its use for the development of skills and abilities of oral dialogical expressions. In the process of using the exercises to identify the development of skills and abilities in speech communication, pupils are expected to:

1) mobilize his / her life experience related to the topic, or the facts necessary for its disclosure;

2) group the information in such a way as to create logical units (prosaic stanzas) that could reveal the micro-thesis of the statement;

3) integrate information from different sources into the statement on the given topic;

4) express their personal attitude, assessment of events, facts and phenomena.

The first stage (pretext) is implemented before reading the text. Exercises at this stage are aimed at predicting content and semantic information of the text, as well as the removal of possible difficulties in the phonetic, lexical and grammatical nature.

The second stage (textual) is the reading of the entire text silently. The reading process can take place in the classroom or at home by the teacher's instructions.

The third stage (post-text) involves performing tasks to control the understanding of the content of the text having been read, as well as exercises aimed at assimilating the linguistic means that provide the skills for operating by pupils these tools in their own statements at the level of the phrase or unpublished unity in connection with the content of the text.

The fourth stage is the stage of performing speech exercises, the purpose of which is to develop pupils' abilities to make fluent oral monologues on the basis of semantic information of the text. Exercises with problematic tasks are carried out, which are based not only on information of the text but also on own experience of pupils.

Conclusions and further research prospects. The factor of age peculiarities and interests of pupils is important for the personal development of pupils. Much information can be familiar to pupils and their inclusion into the educational process can reduce its informativity, and thus actualize the cognitive activity of schoolchildren. So, in our further researches we'll propose test materials (according to proposed stages of the activity with texts) which will be used to control the skills and abilities of adolescents at the English lessons.

\section{REFERENCES}

Alderson, J., Clapham, C. \& Wall, D. (1995). Language Test Construction and Evaluation. London: CUP. 310 p.

Bachman, L.F. (1991). Fundamental Considerations in Language Testing. Oxford: Oxford University Press. pp. 116-135. 
Oller, J. (1989). Language Tests at school. A pragmatic approach. London: Longman Group LTD. 492 p.

\title{
ІННОВАЦЙНІ ЗАСОБИ ПЕРЕВІРКИ ЗНАНЬ, УМІНЬ ТА НАВИЧОК ПІДЛІТКІВ НА УРОКАХ ІНОЗЕМНИХ МОВ
}

\author{
Михальчук Наталія \\ доктор психологічних наук, \\ професор, завідувачка кафедри практики англійської мови \\ Рівненського державного гуманітарного університету, \\ м. Рівне, Україна \\ ORCID: 0000-0003-0492-9450 \\ e-mail:natasha1273@ukr.net \\ Івашкевич Ернест \\ кандидат психологічних наук, \\ викладач кафедри практики англійської мови, \\ Рівненського державного гуманітарного університету, \\ м. Рівне, Україна \\ ORCID: 0000-0001-7219-1086 \\ e-mail:ivashkevych.ee@gmail.com
}

\begin{abstract}
Анотація. У статті представлені інноваційні засоби, які використовуються на уроках іноземної мови з метою тестування знань, умінь та навичок учнів, допомагають вчителеві контролювати процес навчання підлітків і спрямовані на розвиток особистості школярів. Розкриті етапи діяльності учнів з текстовим матеріалом, що грунтуються як на текстовій інформації, так і на особистому досвідові підлітків.

Зазначено, що перший етап (передтекстовий) слід реалізовувати перед читанням тексту. Вправи на цьому етапі мають бути спрямовані на прогнозування змістової та смислової інформації тексту, а також на усунення можливих труднощів фонетичного, лексичного та граматичного характеру. Другий етап (текстовий) передбачає читання мовчки всього тексту. Процес читання може здійснюватися в класі або вдома за вказівкою вчителя. Третій етап (післятекстовий) передбачає виконання завдань 3 метою контролю розуміння змісту прочитаного тексту, а також виконання школярами вправ, спрямованих на опанування учнями мовних засобів, які забезпечуватимуть навички роботи учнями 3 текстовими фреймами, вміння будувати на їхній основі власні висловлювання на рівні фразової або надфразової єдності. Четвертий етап - етап виконання мовленнєвих вправ, мета якого розвивати в учнів уміння складати вільні усні монологи на основі смислової інформації тексту. Вправи виконуються одночасно із розв'язанням проблемних завдань, які грунтуються не лише на інформації тексту, а й на власному досвідові учнів.

Запропоновано інноваційні засоби перевірки підлітками прочитаного матеріалу. Зазначено, що переклад, як різновид тесту, може бути диференційований залежно від характеру джерела тексту, способу його презентації, попередньої методичної роботи 3 учнями та організації діяльності на уроці. У середній школі всі типи текстів можуть використовуватися $з$ точки зору їх змістової структури - описовий, розповідний та інформаційний тести тощо. Зміст тексту може бути відтворений повністю або скорочено, може бути як абстрактним, так і вибірковим.
\end{abstract}


Наступний вид тестового завдання - коментар. Сутність цього виду тесту полягає в тому, що доповідач після отримання певної інформації пояснює своє ставлення до тексту та висловлює у зв'язку з цим свою думку узагальнюючого або оціночного характеру. Прикладами завдань створення коментарів можуть бути, наприклад, запрошення, театральна програма, реклама, статті в газетах чи журналах, міжнародні заходи, жартівливі малюнки тощо.

Ключові слова: інноваційні засоби, тестування, передтекстовий етап, текстовий етап, післятекстовий етап, етап виконання мовленнєвих вправ.

Стаття надійшла до редакиї 03. 04. 2020 р. 